\title{
Utilization of Waste Extracts Residual Tobacco Cigarette Manufacturing and Leaves of Mahkota Dewa as a Natural Pesticide for Pest Control Armyworms in Chili Plant
}

\author{
Cahyati $^{a}$, Marlina ${ }^{b}$, Rizqy Nurlestari ${ }^{c}$, Indrasti Dwi Puji lestari ${ }^{d}$, dan Tatang Shabur \\ Julianto ${ }^{\mathrm{e}}$ \\ a,c,d,e Jurusan Kimia FMIPA UII, Yogyakarta, email: ticahya@gmail.com \\ ${ }^{\mathrm{b}}$ Jurusan Pendidikan Kimia FMIPA UII, Yogyakarta
}

\begin{abstract}
The use of pesticides is still considered behind a great benefit for increasing agricultural production. Quite high negative impact of the use of synthetic pesticides to encourage efforts to pursue the empowerment of natural pesticide as alternative to synthetic pesticides. On tobacco and leaves of mahkota dewa found a substance alkaloid that can help ward off attacks, especially armyworm. Has conducted research utilization of waste residual tobacco cigarette manufacturing at a company and leaves of mahkota dewa as a natural pesticide to eradicate the armyworm. The residual tobacco cigarette manufacturing and leaves of mahkota dewa isolated manner extracted with an organic solvent so that the resulting crude extract alkaloids. The resulting crude alkaloid used as a pesticide solution sprayed on the leaves of chili to eradicate the pest armyworms. Test result showed that the insecticidal activity of alkaloid extract concentration of 1,6 ppm has the highest insecticidal activity. However, engaging both the alkaloid extract provides insecticidal activity is lower than the alkaloid extract of leaves of mahkota dewa so that the most effective in the use of alkaloid extract of leaves of mahkota dewa. Identification of the alkaloid compounds have been analyzed by TLC. This analysis showed that compound in waste of tobacco cigarette manufacture is nicotine and triterpenoids whereas the alkaloid extract of the leaves of mahkota dewa form of narcotic.
\end{abstract}

Keywords: natural pesticides, alkaloids, armyworm, tobacco, leaves of mahkota dewa

\begin{abstract}
Abstrak
Penggunaan pestisida saat ini masih dilematis dibalik manfaat yang besar bagi peningkatan produksi pertanian. Cukup tingginya dampak negatif dari penggunaan pestisida sintesis mendorong berbagai usaha untuk menekuni pemberdayaan pestisida alami sebagai alternatif pengganti pestisida sintesis. Pada tembakau dan daun mahkota dewa, ditemukan zat alkaloid yang dapat membantu menangkal serangan ulat grayak. Telah dilakukan penelitian pemanfaatan limbah tembakau sisa pembuatan rokok pada suatu perusahaan dan daun mahkota dewa sebagai pestisida alami untuk membasmi ulat grayak. Tembakau sisa pembuatan rokok dan daun mahkota dewa diisolasi dengan cara diekstrak dengan pelarut organic sehingga dihasilkan ekstrak crude alkaloid. Crude alkaloid yang dihasilkan digunakan sebagai larutan pestisida yang disemprotkan pada daun cabai untuk membasmi hama ulat grayak. Uji aktivitas insektisida terhadap ekstrak yang dihasilkan sangat efektif digunakan sebagai pestisida. Hal ini karena semakin tinggi konsentrasi ekstrak alkaloid semakin besar tingkat aktivitas insektisidanya. Hasil uji aktivitas insektisida menunjukkan bahwa ekstrak alkaloid tembakau sisa pembuatan rokok dan daun mahkota dewa konsentrasi 1,6 ppm memiliki aktivitas insektisida tertinggi. Namun,

Utilization of Waste Extracts Residual Tobacco Cigarette Manufacturing and Leaves of Mahkota Dewa as a Natural Pesticide for Pest Control Armyworms in Chili Plant
\end{abstract}

(Cahyati, Marlina, Rizqy Nurlestari, Indrasti Dwi Puji lestari, dan Tatang Shabur Julianto) 
ekstrak percampuran kedua alkaloid tersebut memberikan aktivitas insektisida lebih rendah dibanding ekstrak alkaloid daun mahkota dewa sehingga paling efektif pada penggunaan ekstrak alkaloid daun mahkota dewa. Identifikasi senyawa alkaloid telah dianalisis dengan KLT. Hasil analisis menunjukkan senyawa pada ekstrak alkaloid tembakau sisa pembuatan rokok berupa senyawa nikotin dan triterpenoid sedangkan pada ekstrak daun mahkota dewa berupa narkotine.

Kata Kunci: pestisida alami, alkaloid, ulat grayak, tembakau, daun mahkota dewa

\section{Pendahuluan}

Cabai merupakan salah satu tanaman yang mempunyai potensi besar, dari jaman dahulu hingga sekarang cabai masih diburu masyarakat untuk dikonsumsi. Budidaya tanaman cabai selalu dilakukan, namun hama pengganggu pada tanaman cabai yaitu hama ulat yang sering merusak daun dan buah cabai itu sendiri (Julaily, dkk, 2013). Ulat grayak merupakan salah satu hama pada tanaman cabai. Ulat grayak mampu memakan habis seluruh daun dan hanya menyisakan tulang-tulang daun, sedangkan pada serangan berat ulat grayak mampu menurunkan produktivitas tanaman bahkan hingga kegagalan panen (Mardiningsih, dkk, 2011).

Pestisida adalah bahan yang digunakan untuk mengendalikan berbagai hama. Menurut para petani jenis hama yaitu tungau, tumbuhan pengganggu, penyakit tanaman yang disebabkan oleh fungi (jamur), bakteria, dan virus, nematoda (cacing yang merusak akar), siput, tikus, burung dan hewan lain yang dianggap merugikan (Djojosumarto,
2008). Penggunaan pestisida sintesis secara kontinyu dapat mengakibatkan kerusakan pada lingkungan dan gangguan kesehatan (Adriyani, 2006). Pengguanaan pestisida sintesis dapat menyebabkan kerusakan lingkungan yang diakibatkan oleh pencemaran pada tanah, air, tumbuhan, dan rusaknya rantai makanan suatu ekosistem. Akibat dampak negatif tersebut akhir-akhir ini masyarakat cenderung menggunakan pestisida alamiyang ramah lingkungan (Atmaja, 2011).

Berbagai macam cara dapat dilakukan untuk menanggulangi dan mengurangi dampak pencemaran oleh pestisida sintesis, antara lain dengan pencegahan, pengurangan penggunaan pestisida, dan penggunaan pestisida alami. Tanaman atau tumbuhan yang berasal dari alam dan potensial sebagai pestisida nabati umumnya mempunyai karakteristik rasa pahit (mengandung alkaloid dan terpen), berbau busuk dan berasa agak pedas. Tanaman ini jarang diserang oleh hama sehingga banyak digunakan sebagai ekstrak pestisida alami

Utilization of Waste Extracts Residual Tobacco Cigarette Manufacturing and Leaves of Mahkota Dewa as a Natural Pesticide for Pest Control Armyworms in Chili Plant 
dalam pertanian organik (Hasyim, A., dkk, 2010). Pengurangan penggunaan pestisida di areal pertanian menuntut tersedianya cara pengendalian lain yang aman dan ramah lingkungan, diantaranya dengan memanfaatkan musuh alami dan penggunaan pestisida nabati (Samsudin, 2008).

Metabolit sekunder dapat dijadikan penangkal serangga antara lain yaitu dari golongan alkaloid dan terpenoid. Metabolit dari golongan alkaloid umum ditemukan pada tanaman yang dapat menangkis serangan serangga. Metabolit ini ditemukan antara lain, mahkota dewa. Beberapa hasil penelitian diketahui bahwa daun mahkota dewa mengandung metabolit sekunder seperti alkaloid, terpenoid, saponin dan flavonoid yang banyak dimanfaatkan dalam bidang industri farmasi (Gangga, 2007).

Adapun tanaman lain yaitu tembakau, gadung, sereh, dan masih banyak lagi yang dapat dipakai sebagai bahan pestisida alami (Hasanah, M, dkk, 2012). Tembakau (Nicotianaetabacum L) merupakan salah satu jenis tanaman yang dapat digunakan sebagai pestisida alami. Tanaman tembakau dapat dijadikan sebagai pestisida organik karena kandungan nikotinnya yang tinggi mampu mengusir hama pada tanaman, sehingga tembakau bukan hanya digunakan untuk konsumsi rokok semata, tetapi bisa diolah menjadi pestisida alamiah (Yuphy, 2011).

Dalam penelitian ini akan dilakukan isolasi, identifikasi senyawa alkaloid dalam ekstrak metanol menggunakan KLT dan uji aktivitas insektisida terhadap ulat grayak agar limbah tembakau sisa pembuatan rokok pada suatu perusahaan dan daun mahkota dewa bermanfaat sebagai pestisida alami. Hal ini dilakukan dengan tujuan untuk mengurangi kuantitas penggunaan pestisida sintesis antara lain dengan mengintroduksi pestisida alami yang mampu menandingi keampuhan pestisida sintesis.

\section{Tujuan Penelitian}

Adapun tujuan dari penelitian ini yaitu:

1. Menentukan pengaruh konsentrasi ekstrak alkaloid dari limbah tembakau sisa pembuatan rokok dan daun mahkota dewa terhadap hama ulat grayak pada tanaman cabai.

2. Menentukan tingkat efektivitas aktivitas insektisida antara ekstrak alkaloid dari limbah tembakau sisa pembuatan rokok dan daun mahkota

Utilization of Waste Extracts Residual Tobacco Cigarette Manufacturing and Leaves of Mahkota Dewa as a Natural Pesticide for Pest Control Armyworms in Chili Plant 
dewa terhadap hama ulat grayak pada tanaman cabai.

3. Menentukan kandungan senyawa yang terdapat pada ekstrak alkaloid dari limbah tembakau sisa pembuatan rokok dan daun mahkota dewa.

\section{Metode Penelitian}

\section{Peralatan yang digunakan}

Peralatan yang digunakan

adalah Set magnetik stirrer, heating mantel, peralatan gelas, evaporator, reaktor soklet, botol spray, peralatan uji KLT, dan Lampu UV.

\section{Bahan yang digunakan}

Bahan yang digunakan dalam penelitian ini adalah limbah tembakau sisa pembuatan rokok, daun mahkota dewa, ulat grayak (Spodopteralitura F.), pelarut organik (metanol, etanol, kloroform, benzena), $\mathrm{NH}_{4} \mathrm{OH}, \mathrm{H}_{2} \mathrm{SO}_{4}$ pekat, asam asetat anhidrat, kertas saring, larutan tween 80, daun cabai, dan air.

\section{Cara Kerja}

\section{Isolasi dan Ekstraksi Senyawa Alkaloid}

Sampel daun mahkota dewa dan limbah rokok masing-masing disiapkan dan dipotong sedemikian rupa sehingga ukurannya kecil-kecil. Kemudian masing- masing dibungkus kertas saring dan dimasukkan dalam reaktor sokhlet. Sampel disokletasi dengan pelarut metanol. Ekstrak yang diperoleh selanjutnya diuapkan dengan rotary evaporator dalam kondisi vakum sampai diperoleh ekstrak crude. Crude yang diperoleh diasamkan dengan $5 \% \mathrm{H}_{2} \mathrm{SO}_{4}$ kemudian disaring. Filtrat dibasakan dengan $\mathrm{NH}_{4} \mathrm{OH}$ sampai $\mathrm{pH}$ 11, kemudian diekstraksi dengan kloroform untuk menghasilkan crude alkaloid (Julianto, 2008).

\section{Identifikasi Senyawa Alkaloid}

Keberadaan senyawa alkaloid dalam ekstrak diidentifikasi menggunakan uji Kromatografi Lapis Tipis (KLT) dengan berbagai eluen untuk uji kandungan narcotine pada ekstrak daun mahkota dewa serta uji kandungan nikotin pada ekstrak limbah tembakau sisa pembuatan rokok.

Crude alkaloid yang dihasilkan ditotolkan ke plat KLT kemudian plat tersebut dimasukkan ke dalam chamber yang berisi eluen. Ditunggu sampai dihasilkan bercak warna yang menandakan pemisahan senyawa pada crude alkaloid tersebut. Bercak yang dihasilkan diidentifikasi dengan lampu UV. Dari hasil ini akan diketahui nilai Rf dari masing-masing jenis eluennya. Kemudian dibandingkan nilai $\mathrm{Rf}$ yang 
dihasilkan dengan literatur.

Selain itu dilakukan pengujian uji screening untuk menguji kandungan senyawa fenolik dengan penyemprotan larutan $\mathrm{FeCl}_{3}$ serta uji terhadap adanya senyawa triterpenoid dengan reagen Lieberman Burchard yaitu reagen yang terdiri dari $10 \mathrm{~mL}$ asam asetat anhidrat dengan $10 \mathrm{~mL}$ asam sulfat pekat.

\section{Uji Aktivitas Insektisida}

Pembuatan larutan pestisida dari ekstrak limbah tembakau sisa pembuatan rokok, ekstrak daun mahkota dewa dan percampuran antara ekstrak limbah tembakau sisa pembuatan rokok dan daun mahkota dewa. Larutan pestisida dibuat dengan konsentrasi masing-masing 0,4; 0,$6 ; 0,8 ; 1,0 ; 1,2 ; 1,4 ;$ dan 1,6 ppm. Pembuatan larutan pestisida dilakukan dengan bantuan surfaktan larutan tween 80 yang sebanding dengan banyaknya volume ekstrak yang dilarutkan dengan air. Kemudian dihomogenkan dengan bantuan magnetic stirer.

Sejumlah daun cabai (3 lembar) disemprot ekstrak daun mahkota dewa, ekstrak limbah rokok serta ekstrak campuran antara daun mahkota dewa dan limbah rokok dengan konsentrasi yang berbeda $(0,4 ; 0,6 ; 0,8 ; 1,0 ; 1,2 ; 1,4$ dan 1,6 ppm). Untuk kontrol daun cabai disemprot dalam ekstrak dengan konsentrasi 0 ppm. Setelah agak kering daun cabai dimasukkan dalam cup plastik kemudian dimasukkan ulat grayak sejumlah masing-masing 4 ekor kemudian ditutup rapat. Perlakuan diatas dibuat 3 replikan. Pada hari berikutnya (pagi hari) masing-masing uji diamati jumlah ulat yang mati.

\section{Hasil dan Pembahasan}

Isolasi dan Ekstraksi Senyawa Alkaloid

Sebanyak 500 gram daun mahkota dewa dan 250 gram limbah rokok dipotong-potong kecil. Maksud dari pemotongan ini yaitu untuk memperkecil ukuran sehingga mudah pada saat diekstraksi serta sel-sel dalam daun maupun limbah akan terbuka sehingga mudah terekstrakkan. Selanjutnya sampel disokhletasi dengan pelarut metanol selama 6 jam. Hasil ini dievaporasi untuk menguapkan komponen metanol sehingga dihasilkan crude ekstrak. Crude ekstrak diasamkan dengan asam sulfat $5 \%$ dan disaring. Tujuan dari pengasaman ini adalah untuk mengubah alkaloid menjadi garam alkaloid. Alkaloid merupakan senyawa yang tidak larut dalam air. Agar senyawa ini dapat dipisahkan dengan pelarut air maka alkaloid terlebih dahulu diubah menjadi bentuk garamnya. Karena sifatnya yang basa dengan keberadaan atom nitrogen pada strukturnya, maka 
senyawa alkaloid dapat diubah dalam bentuk garamnya dengan penambahan asam.

Pada saat pengasaman, maka senyawa-senyawa selain garam alkaloid akan mengendap dan selanjutnya disaring. Filtrat yang diperoleh merupakan ekstrak alkaloid kasar. Ekstrak asam dibasakan dengan ammonium hidroksida hingga mencapai pH 11. Maksud pemberian basa ini adalah untuk membebaskan alkaloid dari bentuk garamnya, karena pada pH 11 garam alkaloid akan kembali menjadi alkaloid bebas secara optimal. Setelah itu diekstrak dengan pelarut organik yaitu kloroform. Ekstrak kloroform dievaporasi untuk menguapkan kloroform sehingga dihasilkan crude alkaloid.

\section{Identifikasi Senyawa Alkaloid}

\section{Pemisahan dengan menggunakan}

\section{Kromatografi Lapis Tipis}

Penentuan eluen dalam proses KLT sangat menentukan harga Rf yang dihasilkan nantinya. Selain itu kondisi plat KLT juga mempengaruhi proses pemisahan. Plat sebaiknya dalam kondisi kering (tidak mengikat air), karena dengan adanya air akan mempengaruhi proses pemisahan. Sehingga pada proses ini sangat hati-hati. Kemiringan dan jumlah sampel yang ditotolkan juga harus diperhatikan hal ini karena dapat menghasilkan bercak yang tidak sesuai (berekor) sehingga sangat berpengaruh pada Rf yang dihasilkan. Hasil pemisahan diidentifikasi keberadaan bercak dengan lampu UV. Tabel 1 merupakan hasil pemisahan ekstrak alkaloid dengan plat KLT pada berbagai eluen.

Tabel 1. Hasil pemisahan pada plat KLT pada berbagai eluen terhadap ekstrak alkaloid

\begin{tabular}{|c|c|c|c|c|}
\hline Ekstrak Alkalod & $\begin{array}{c}\text { Jenis alkaloid } \\
\text { yang diuji }\end{array}$ & Eluen & $\begin{array}{c}\text { Rf } \\
\text { Eksperimen }\end{array}$ & $\begin{array}{c}\text { Rf } \\
\text { literatur }\end{array}$ \\
\hline \multirow{3}{*}{$\begin{array}{c}\text { Daun Mahkota } \\
\text { Dewa }\end{array}$} & narcotine & $\mathrm{CHCl}_{3}$ & 0,77 & 0,77 \\
\cline { 3 - 5 } & & $\mathrm{CHCl}_{3}: \mathrm{EtOH}(8: 2)$ & 0,8 & 0,81 \\
\cline { 3 - 5 } & & $\mathrm{CHCl}_{3}: \mathrm{EtOH}(9: 1)$ & 0,8 & 0,78 \\
\cline { 3 - 5 } & & $\mathrm{C}_{6} \mathrm{H}_{6}: \mathrm{EtOH}(9: 1)$ & 0,96 & 0,9 \\
\cline { 3 - 5 } & $\mathrm{C}_{6} \mathrm{H}_{6}: \mathrm{EtOH}:$ Aseton & 0,74 & 0,78 \\
& $(70: 15: 15)$ & & 0,57 \\
\hline Limbah Rokok & nikotin & $\mathrm{MeOH}: \mathrm{NH}_{4} \mathrm{OH}$ & 0,56 & 0 \\
\hline
\end{tabular}

Utilization of Waste Extracts Residual Tobacco Cigarette Manufacturing and Leaves of Mahkota Dewa as a Natural Pesticide for Pest Control Armyworms in Chili Plant 
Pada Tabel 1 menunjukkan jenis eluen yang sering digunakan untuk mengidentifikasi alkaloid (Stahl, 1969). Dari harga Rf yang diperoleh, yang dibandingkan dengan literatur, menunjukkan bahwa daun mahkota dewa mengandung jenis alkaloid narcotine. Struktur narkotine dapat dilihat pada Gambar 1:

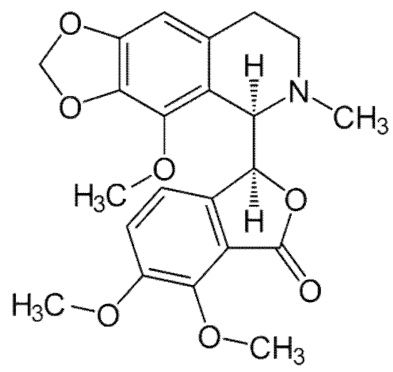

Gambar 1. Struktur narkotine

Sedangkan pada limbah tembakau sisa pembuatan rokok mengandung jenis alkaloid nikotin. Sehingga dari hasil KLT ini dapat diketahui bahwa dalam ekstrak tersebut mengandung senyawa alkaloid. Struktur nikotin dapat dilihat pada Gambar 2:

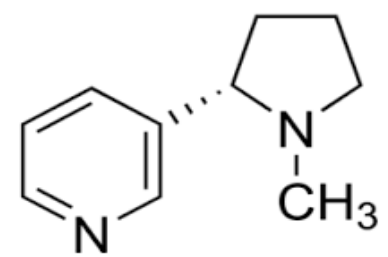

Gambar 2. Struktur nikotin

Hasil uji keberadaan senyawa fenolik dilakukan dengan cara hasil KLT diatas dilakukan penyemprotan dengan larutan $\mathrm{FeCl}_{3}$. Dari hasil uji yang dilakukan antara ekstrak limbah tembakau sisa pembuatan rokok dan ekstrak daun mahkota dewa tidak terbentuknya warna ketika disemprot sehingga dapat diketahui bahwa pada ektrak tersebut tidak mengandung senyawa fenolik.

\section{Pengujian dengan Reagen Lieberman}

Burchard

Hasil uji terhadap reagen Lieberman Burchard dilakukan dengan penggunaan KLT dengan eluen yang digunakan berupa larutan benzena : kloroform (7 : 3). Dari hasil KLT disemprotkan reagen tersebut berupa larutan $10 \mathrm{~mL}$ asam asetat anhidrat dan $10 \mathrm{~mL}$ asam sulfat pekat. Dari hasil uji ini dihasilkan bahwa pada ekstrak limbah tembakau sisa pembuatan rokok menghasilkan bercak warna merah. Hal ini dapat diketahui bahwa ekstrak tersebut mengandung senyawa triterpenoid.

\section{Aktivitas Ulat Grayak Terhadap Pestisida Alami}

Hasil uji aktivitas insektisida ekstrak alkaloid limbah tembakau sisa pembuatan rokok disajikan pada Tabel 2. 
Tabel 2. Hasil uji aktivitas insektisida limbah pabrik rokok terhadap ulat Grayak (Spodoptera litura)

\begin{tabular}{|c|c|c|c|c|c|c|c|c|}
\hline \multirow{2}{*}{ Alat uji } & \multicolumn{9}{|c|}{ Jumlah ulat yang mati } \\
\cline { 2 - 10 } & \multicolumn{9}{|c|}{ Konsentrasi ekstrak (ppm) } \\
\cline { 2 - 10 } & 0,0 & 0,4 & 0,6 & 0,8 & 1,0 & 1,2 & 1,4 & 1,6 \\
\hline 1 & 0 & 0 & 2 & 2 & 3 & 3 & 4 & 4 \\
\hline 2 & 0 & 0 & 2 & 4 & 2 & 4 & 4 & 4 \\
\hline 3 & 0 & 0 & 3 & 2 & 3 & 4 & 4 & 4 \\
\hline Rata-rata & 0 & 0 & 2,33 & 2,67 & 2,67 & 3,67 & 4 & 4 \\
\hline
\end{tabular}

Pada Tabel 2 menunjukkan bahwa ekstrak alkaloid semakin tinggi konsentrasi aktivitas insektisida makin tinggi. Hal ini diketahui pada konsentrasi 1,4 ppm ulat grayak telah mati semua. Bila dibandingkan daun yang tidak

Tabel 3. Hasil uji aktivitas insektisida daun mahkota dewa terhadap ulat Grayak (Spodoptera litura)

\begin{tabular}{|c|c|c|c|c|c|c|c|c|}
\hline \multirow{2}{*}{ Alat uji } & \multicolumn{9}{|c|}{ Jumlah ulat yang mati } \\
\cline { 2 - 10 } & \multicolumn{9}{|c|}{ Konsentrasi ekstrak (ppm) } \\
\cline { 2 - 10 } & 0,0 & 0,4 & 0,6 & 0,8 & 1,0 & 1,2 & 1,4 & 1,6 \\
\hline 1 & 0 & 1 & 2 & 1 & 3 & 4 & 4 & 4 \\
\hline 2 & 0 & 1 & 1 & 4 & 4 & 4 & 4 & 4 \\
\hline 3 & 0 & 1 & 3 & 2 & 3 & 4 & 4 & 4 \\
\hline Rata-rata & 0 & 1 & 2 & 2,33 & 3,33 & 4 & 4 & 4 \\
\hline
\end{tabular}

Data Tabel 3 menunjukkan bahwa ekstrak alkaloid semakin tinggi konsentrasi aktivitas insektisida makin tinggi. Hal ini diketahui pada konsentrasi 1,2 ppm ulat grayak telah mati semua. Bila dibandingkan daun yang tidak disemprot (konsentrasi ekstrak alkaloid 0 ppm) tidak memberikan aktivitas insektisida. Dengan demikian dapat disemprot (konsentrasi ekstrak alkaloid 0 ppm) tidak memberikan aktivitas insektisida. Hasil uji aktivitas insektisida ekstrak alkaloid daun mahkota dewa disajikan pada Tabel 3. 
Tabel 4. Hasil uji aktivitas insektisida percampuran ekstrak limbah tembakau sisa pembuatan rokok dan daun mahkota dewa terhadap ulat Grayak (Spodoptera litura)

\begin{tabular}{|c|c|c|c|c|c|c|c|c|}
\hline \multirow{3}{*}{ Alat uji } & \multicolumn{7}{|c|}{ Jumlah ulat yang hidup } \\
\cline { 2 - 9 } & \multicolumn{9}{|c|}{ Konsentrasi ekstrak (ppm) } \\
\cline { 2 - 9 } & 0,0 & 0,4 & 0,6 & 0,8 & 1,0 & 1,2 & 1,4 & 1,6 \\
\hline 1 & 0 & 0 & 1 & 2 & 3 & 3 & 4 & 4 \\
\hline 2 & 0 & 0 & 1 & 3 & 2 & 2 & 3 & 4 \\
\hline 3 & 0 & 1 & 0 & 3 & 3 & 3 & 4 & 4 \\
\hline Rata-rata & 0 & 0,33 & 0,67 & 2,67 & 2,67 & 2,67 & 3,67 & 4 \\
\hline
\end{tabular}

Data Tabel 4 menunjukkan aktivitas insektisida terhadap ekstrak alkaloid secara optimal terjadi pada konsentrasi 1,6 ppm. Hal ini diketahui pada konsentrasi 1,6 ppm ulat grayak telah mati semua. Bila dibandingkan daun yang tidak disemprot (konsentrasi ekstrak alkaloid 0 ppm) tidak memberikan aktivitas insektisida.

\section{Kesimpulan}

Dari hasil penelitian yang dilakukan ini dapat diperoleh kesimpulan yaitu:

1. Semakin tinggi konsentrasi ekstrak alkaloid pada tembakau sisa pembuatan rokokdan daun mahkota dewa semakin besar tingkat aktivitas insektisidanya. Aktivitas tertinggi yaitu pada konsentrasi 1,6 ppm.

2. Ekstrak percampuran kedua alkaloid tersebut memberikan aktivitas insektisida lebih rendah dibanding ekstrak alkaloid daun mahkota dewa sehingga paling efektif pada penggunaan ekstrak alkaloid daun mahkota dewa

3. Kandungan senyawa pada ekstrak alkaloidtembakau sisa pembuatan rokok berupa senyawa nikotin dan triterpenoid sedangkan pada ekstrak daun mahkota dewa berupa narkotine.

\section{Daftar Pustaka}

Adriyani, R., 2006, Usaha Pengendalian Pencemaran Lingkungan akibat Penggunaan Pestisida Pertanian, Surabaya, Universitas Airlangga, Jurnal Kesehatan Lingkungan, 3(1), 2006, 95-106

Anonim. Posted 3 November 2011. Budidaya tanaman tembakau http://yuphyyehahaa.glogspot.co $\underline{\mathrm{m} / 2011 / 11 / \text { budidaya-tanaman- }}$ tembakau.html. Diakses tanggal 1 September 2015

Atmaja, W. R., 2011, Pemanfaatan Lima Jenis Insektisida Nabati Untuk Mengendalikan Ulat Grayak (Spodoptera litura) pada Tanaman Cabe, Semnas Pesnab, 4: $163-176$

Utilization of Waste Extracts Residual Tobacco Cigarette Manufacturing and Leaves of Mahkota Dewa as a Natural Pesticide for Pest Control Armyworms in Chili Plant 
Djojosumarto, P., 2008, Pestisida dan Aplikasinya, Agromedia Pustaka, Jakarta

Egon, Stahl, 1969, Thin Layer Chromatography Handbook. Translate by M.R.F Asworth, Toppan Printing, Singapore

Gangga E., H. Asriani dan L., Novita., 2007, Analisis Pendahuluan Metabolit Sekunder dari Kalus Mahkota Dewa (Phaleria macropora [Scheff.] Boerl.), Jurnal Ilmu Kefarmasian Indonesia: $17-22$

Hasanah, M., Tangkas Made I, Sakung J., 2012, Daya Insektisida Alami Kombinasi Perasan Umbi Gadung (Dioscorea Hispida Dennst) dan Ekstrak Tembakau (Nicotiana Tabacum L), Palu : Universitas Tadulako, Jurnal akademi kimia, 1(4), 2012, 166173

Hasyim, A., 2010, Efikasi dan Persistensi Minyak Sereh Wangi sebagai Biopestisida terhadap Helicoverpa aemigera, Balai Penelitian Tanaman Sayuran, Lembang
Julaily, N., Mukarlina, dan Setyawati T. R., 2013, Pengendalian Hama pada Tanaman Sawi (Brassica juncea L.). Menggunakan Ekstrak Daun Pepaya (Carica papaya L.), Jurnal Protobiont, 2(3): 171-175

Julianto, Tatang, S., 2008, Isolasi dan Identifikasi Senyawa Alkaloid Ekstrak Etanol Daun Mahkota Dewa (Phaleria macrocarpa (Scheff.) Boerl.) dan Uji Aktivitasnya Sebagai Insektisida terhadap ulat grayak (Spodoptera litura (Fab.)), Eksakta Jurnal Ilmu-Ilmu MIPA, Universitas Islam Indonesia, Yogyakarta

Mardiningsih, T. L., N. C. Salam, dan C. Sukmana, 2011, Pengaruh Beberapa Jenis Insektisisda Nabati Terhadap Mortalitas Spodoptera litura (lepidoptera: Noctuidae), Semnas Pesnab, 4: 51-60

Samsudin, 2008, Virus Patogen Serangga: Bio - Insektisida Ramah Lingkungan, http://www.pertaniansehat.or.od. Diakses 5 September 2015 